\title{
Estadística de fractura por torsión y relaciones de dispersión en barras circulares
}

\section{Fracture statistics of torsion and dispersion relations in round bars}

\author{
G. DÍAZ \\ Departamento de Ciencia e Ingeniería de Materiales (IDIEM), \\ Facultad de Ciencias Físicas y Matemáticas, Universidad de Chile,

\section{RESUMEN}

Se estudió desde un punto de vista teórico la estadística de fractura de barras de sección circular sometidas a torsión y se determinó las probabilidades acumulativas de fractura usando la función riesgo específico de Weibull para materiales con fragilidades volumétrica y superficial. Mediante el método de las funciones definidas se obtuvo la función riesgo específico de fractura, además se separó la parte volumétrica de la parte superficial para materiales que poseen ambas fragilidades. La dispersión de los parámetros se determinó con la matriz de información de Fisher.

\begin{abstract}
This paper has adopted a theoretical wiewpoint for studying Fracture Statistics in round bars subjected to torsion, and for determining the cumulative probabilities of fracture using Weibll's specific-risk function for materials that exhibit volume and surface brittleness. The use of the defined-functions method has allowed to get the specific-risk-of-fracture function and, in addition, to carry out a separation between volume part and surface part concerning materials presenting both brittlenesses at the same time. Dispersion of the parameters are
\end{abstract} determined resorting to Fisher's information matrix.

\section{INTRODUCCIÓN}

En la actualidad se usa ampliamente la mecánica estadística de fractura, propuesta por Weibull [1], para describir el comportamiento a la fractura de materiales frágiles. Las investigaciones han estado dirigidas a diversos aspectos, entre ellos: sus fundamentos [2, 3]; su aplicación a la obtención de la probabilidad acumulativa de fractura de diversos materiales sometidos a distintos estados de tensión como los biaxiles [4] y los multiaxiles [5]; torsión [6-9]; flexión [10]; estimación de los parámetros de Weibull $[11,12]$. El objetivo de este trabajo es el estudio teórico del problema de la torsión, determinando las probabilidades acumulativas de fractura, los parámetros de la funcion riesgo específico de fractura y las dispersiones de los mismos.

\section{INTRODUCTION}

Statistical mechanics of fracture proposed by Weibull [1] is now being widely used for describing the fracture behaviour of brittle materials. Investigation has been directed to diverse aspects such as: the foundations of said mechanics [2, 3]; the application thereof for getting the cumulative probability of fracture concerning sundry materials subjected to different states of stress as for instance biaxial [4] and multiaxial [5] states, torsion [6-9], bending [10]; the evaluation of Weibull's parameters $] 11,12]$. This work is endeavouring to achieve the theoretical study of the torsion problem determining therefor the cumulative probabilities of fracture, the parameters of the specific-risk-of-fracture function, and the dispersion of the same. 


\section{ESTADISTICA DE FRACTURA POR TORSION}

\subsection{Fragilidad volumétrica}

De acuerdo con la teoría de Weibull la probabilidad acumulativa de fractura $F(\tau)$ para materiales con fragilidad volumétrica sometidos a un estado uniaxil de tensiones de corte es:

\section{STATISTICS OF FRACTURE THROUGH TORSION}

\subsection{Volume brittleness}

The cumulative probability of fracture $F(\tau)$ for materials with volume brittleness and subjected to some uniaxil state of shear stress is as follows according to Weibull's theory:

$$
F(\zeta)=1-\exp \left\{-\frac{1}{V_{0}} \int_{V} \phi[\sigma(r)] d V\right\}
$$

donde $V_{0}$ es la unidad de volumen, $V$ es el volumen del cuerpo, $r$ es el vector posición, $\tau$ es el esfuerzo máximo de corte que alcanza el material antes de romperse, $\tau(r) \leqq \tau$ es el campo uniaxil de tensiones y $\Phi(\tau)$ es la función riesgo específico de fractura. Weibull [1] propuso para ella la siguiente forma analítica: where $V_{0}$ is the volume unit, $V$ is the body volume, $r$ is the position vector, $\tau$ is the maximun shear-stress reached in the material before breaking, $\tau(r) \leqq \tau$ is the uniaxil stress-field, and $\Phi(\tau)$ is the specific-risk-of-fracture function. Weibull [1] has proposed the following analytical form for this function:

$$
\phi(\sigma)= \begin{cases}\left(\frac{\sigma-\sigma_{L}}{\sigma_{0}}\right)^{m} & \sigma \geqslant \sigma_{L} \\ 0 & \sigma<\sigma_{L}\end{cases}
$$

donde $\tau_{0}$ y $\mathrm{m}$ son parámetros que dependen del proceso de fabricación del material mientras que $\tau_{L}$ es el esfuerzo bajo el cual no hay rotura.

De acuerdo con la teoría elemental de la torsión, el campo de tensiones en coordenadas cilíndricas para una barra, con fragilidad volumétrica, de sección circular de radio $r$ y longitud $L$ está dado por: where $\tau_{0}$ and $m$ parameters depending on the manufacturing process of the material, while $\tau_{L}$ is the stress under which there is no fracture.

In accordance with the elemental theory of torsion, the stress field, in cilindrical coordinates, for a round bar exhibiting volume brittleness and $L$ in length and $r$ in radius, may be expressed as follows:

$$
\begin{aligned}
& \sigma(\rho)=\frac{\rho}{r} \sigma \leqslant \sigma=\frac{2 M}{\pi r^{3}} \\
& 0 \leqslant \rho \leqslant r ; 0 \leqslant \theta \leqslant 2 \pi ; 0 \leqslant z \leqslant L
\end{aligned}
$$

donde $M$ es el momento de torsión actuando sobre la barra. Reescribiendo la ecuación (1) se obtiene: where $M$ is the torsional moment acting on the bar. The rewriting of equation (1) gives:

$$
\xi(\tau)=\ln \frac{1}{1-F(\tau)}=\frac{1}{V_{0}} \int_{V} \phi[\sigma(r)] d V
$$


Si $\Phi(\tau)$ está dada por la ecuación (2), i.e., empleando el método de las funciones definidas, y considerando las ecuaciones (3) y (4) se obtiene:
If $\Phi(\tau)$ is given by equation (2) i.e. using the defined functions method and considering the above equations (3) and (4) we get:

$$
\xi(\sigma)=\frac{2 \pi L r^{2}}{V_{0}(m+2)} \frac{\sigma_{0}}{\sigma}\left[1+\frac{1}{m+1} \frac{\sigma_{L}}{\sigma}\right]\left(\frac{\sigma-\sigma_{L}}{\sigma_{0}}\right)^{m+1}
$$

Si $\tau_{\mathrm{L}}=0$ en la ecuación (2), tomando en cuenta las ecuaciones (3) y (4) entonces:

If $\tau_{L}=0$ in equation (2), the consideration of equations (3) and (4) yields:

$$
\xi(\tau)=\frac{2 \pi L r^{2}}{V_{0}(m+2)}\left(\frac{\zeta}{\sigma_{0}}\right)^{m}
$$

Los parámetros de Weibull $m, \tau_{0}$ y $\tau_{1}$ pueden obtenerse a partir de la ecuación (5) ya que $\xi(\tau)$ se conoce de los ensayos. Si $\tau_{L}=0$ se puede confeccionar un diagrama de Weibull y obtener los parámetros $m$ y $\tau_{0}$ usando la ecuación (6).

\subsection{Fragilidad superficial}

En el caso de materiales con fragilidad superficial, de acuerdo con la teoría de Weibull, la probabilidad acumulativa de fractura $F(\tau)$ está dada por una expresión análoga a la ecuación (1) y podemos escribirla como la ecuación (4).

$$
\xi(\tau)=\ln \frac{1}{1-F(\tau)}=\frac{1}{S_{0}} \int_{S} \phi[\sigma(r)] d S
$$

donde $S_{0}$ es la unidad de superficie y $S$ es la superficie del material.

De acuerdo con la teoría elemental de la torsión, el campo de tensiones para una barra, con fragilidad superficial, de sección circular de radio $r$ y longitud $L$ está dado por:
Weibull's parameters $m, \tau_{0}$ and $\tau_{L}$ may be obtained from equation (5) inasmuch as $\xi(\tau)$ is known from the tests. If $\tau_{L}=0$ a Weibull diagram may be plotted, and parameters $m$ and $\tau_{0}$ may be obtained using the equation (6).

\subsection{Surface brittleness}

In the case of materials with surface brittleness, according to Weibull's theory the cumulative probability of fracture $F(\tau)$ is given by an expression similar to equation (1) and that may be written in the following way, as equation (4): where $S_{0}$ is surface unit and $S$ is the surface of the material.

In accordance with the elemental theory of torsion, the stress field for a round bar exhibiting surface brittleness and $L$ in length and $r$ in radius may be expressed as follows:

$$
\begin{aligned}
& \tau(\rho=r)=\tau \\
& 0 \leqslant \theta \leqslant 2 \pi ; \quad 0 \leqslant z \leqslant L
\end{aligned}
$$

Si $\Phi(\tau)$ viene dado por la función de Weibull, ecuación (2), luego considerando las 
ecuaciones (7) y (8) se tiene:

$$
\xi(\tau)=\frac{2 \pi L r}{s_{c}}\left(\frac{\sigma-\sigma_{L}}{\sigma_{0}}\right)^{m}
$$

Si $\tau_{\mathrm{L}}=0$ en la ecuación (2), entonces considerando las ecuaciones (7) y (8) se tiene:
If $\tau_{L}=0$ in equation (2), then equations (7) and (8) allow to get.

$$
\xi(\sigma)=\frac{2 \pi L r}{S_{0}}\left(\frac{\sigma}{\sigma_{0}}\right)^{m}
$$

Con las ecuaciones (9) y (10) se pueden confeccionar los diagramas de Weibull respectivos para determinar los parámetros $\mathrm{m}, \tau_{0}$ y $\tau_{\mathrm{L}}$, cuando $\tau_{\mathrm{L}} \neq 0$ y $\tau_{\mathrm{L}}=0$, respectivamente.

\subsection{Fragilidad volumétrica y superficial conjunta}

En el caso de torsión de una barra de sección circular con fragilidad volumétrica y superficial, se pueden obtener separadamente las respectivas funciones riesgo específico de fractura. Considerando las ecuaciones (5) y (9) se tiene:
Equations (9) and (10) permit the plotting of the respective Weibull diagrams for getting the parameters $m, \tau_{0}$ and $\tau_{L}$, when $\tau_{L} \neq 0$ and $\tau_{L}=0$, respectively.

\subsection{Combined volume and surface brittlenesses}

In the case of torsion applied to some round bar presenting volume and surface brittlenesses, the respective specific-risk-of-fracture functions may be obtained in a separate manner. Considering equations (5) and (9) we have:

$$
\begin{aligned}
& \xi(\sigma)=\frac{2 \pi L_{L^{2}}}{V_{0}} \phi_{V}(\sigma)+\frac{2 \pi L r}{S_{0}} \phi_{S}(\sigma) \\
& \phi_{V}(\sigma)=\frac{\zeta_{O V}}{\sigma}\left[1+\frac{1}{m_{V}+1} \frac{\sigma_{L V}}{\sigma}\right]\left(\frac{\sigma-\sigma_{L V}}{\sigma_{O V}}\right)^{m_{V}+1} \\
& \phi_{S}(\tau)=\left(\frac{\tau-\tau_{L S}}{\zeta_{O S}}\right)^{m_{S}}
\end{aligned}
$$

y si tomamos dos grupos de muestras con $L_{i}$ y $r_{i}, i=1,2$, se obtienen las siguientes ecuaciones: and if we take two groups of samples with $L_{i}$ and $r_{i}$, where $i=1,2$, then we get the following equations:

$$
\begin{aligned}
& \xi_{1}(\tau)=\frac{2 \pi L_{1} r_{1}^{2}}{V_{0}} \phi_{v}(\tau)+\frac{2 \pi L_{1} r_{1}}{S_{0}} \phi_{s}(\tau) \\
& \xi_{2}(\tau)=\frac{2 \pi L_{2} r_{2}^{2}}{V_{0}} \phi_{v}(\tau)+\frac{2 \pi L_{2} r_{2}}{S_{0}} \phi_{S}(\tau)
\end{aligned}
$$


Este sistema tiene una solución no trivial, ya que si $r_{1} \neq r_{2}$ el determinante asociado a él es no nulo y el sistema es linealmente independiente. Por lo tanto, resolviendo la ecuación (12) para $\Phi_{\mathrm{v}}$ y $\Phi_{\mathrm{s}}$ se obiene:
This system has a non-trivial solution, because if $r_{1} \neq r_{2}$ the associated determinant is not null, and the system is linearly independent. Hence the resolution of equation (12) for getting $\Phi_{v}$ and $\Phi_{s}$ yields:

$$
\begin{aligned}
& \phi_{v}(\tau)=\frac{V_{0}}{2 \pi\left(r_{1}-r_{2}\right)}\left[\frac{\xi_{1}(\tau)}{L_{1} r_{1}}-\frac{\xi_{2}(\tau)}{L_{2} r_{2}}\right] \\
& \phi_{S}(\tau)=\frac{S_{0}}{2 \pi\left(r_{1}-r_{2}\right)}\left[\frac{r_{1}}{L_{2} r_{2}} \xi_{2}(\sigma)-\frac{r_{2}}{L_{1} r_{1}} \xi_{1}(\tau)\right]
\end{aligned}
$$

De esta manera ha sido posible separar ambas funciones riesgo específico de fractura, cuando el material posee en forma conjunta fragilidad volumétrica y superficial. Además los parámetros de las respectivas funciones riesgo específico de fractura, para fragilidad volumétrica y superficial, se pueden evaluar confeccionando un nomograma adimensional [12]. En el caso de fragilidad volumétrica, considerando $\Phi_{v}$ de las ecuaciones (11) y (13) obtenemos:
In this way it has been possible to separate both functions of the specific risk of fracture, when the material is exhibiting volume brittleness and surface brittleness at the same time. Moreover the parameters of the respective specific-risk-of-fracture functions, for volume and surface brittleness, may be evaluated by preparing a non dimesional nomogram [12]. In the case of volume brittleness, considering $\Phi_{V}$ of the equations (11) and (13), we get.

$$
\ln \phi_{V}(\tau)=\ln \left\{\left[1+\frac{\sigma_{L V} / \sigma}{m_{V}+1}\right] \frac{\sigma_{L V}}{\sigma}\left(\frac{\sigma}{\sigma_{L V}}-1\right)^{m_{V}+1}\right\}+\ln \left(\frac{\sigma_{L V}}{\sigma_{V V}}\right)^{m_{V}}
$$

Entonces, graficando:

$$
\ln \left\{\left[1+\frac{\sigma_{L V} / \sigma}{m_{V}+1}\right] \frac{\sigma_{L V}}{\sigma}\left(\frac{\sigma}{\sigma_{L V}}-1\right)^{m_{V}+1}\right\}
$$

versus $\ln \left(\tau_{\mathrm{LV}} / \tau_{\mathrm{OV}}\right)$ para diversos valores del parámetro de Weibull $\mathrm{m}_{\mathrm{v}}$ podemos obtener un nomograma y, entonces, el mejor ajuste de los puntos experimentales sobre una curva del nomograma arrojará los valores de $\mathrm{m}_{\mathrm{v}}, \tau_{\mathrm{ov}} \mathrm{y}$ $\tau_{L V}$. Para el caso de fragilidad superficial, considerando $\Phi_{\mathrm{s}}$ de las ecuaciones (11) y (13) obtenemos: against In $\left(\tau / \tau_{L V}\right)$ for several values of Weibull's parameter $m_{V}$ we obtain the nomogram, and the best fits the experimental points on the nomogram curve allows to obtain $m_{v}$, $\tau_{o v}$ and $\tau_{L V}$. In the case of surface brittleness, considering $\Phi_{S}$ of the equations (11) and (13), we get.

$$
\ln \phi_{S}(\sigma)=m_{S} \ln \left(\frac{\sigma}{\sigma_{L S}}-1\right)+\ln \left(\frac{\sigma_{L S}}{\sigma_{O S}}\right)^{m_{S}}
$$

Ahora si graficamos $m_{s} \ln \left(\tau / \tau_{L S}-1\right)$ versus In $\left(\tau / \tau_{\mathrm{LS}}\right)$ para diversos valores del módulo de Weibull $\mathrm{m}_{\mathrm{s}}$ obtenemos un gráfico
Now if we plot $m_{s} \ln \left(\tau / \tau_{L S}-1\right)$ against $\ln \left(\tau / \tau_{L S}\right)$ for various values of Weibull's modulus $m_{s}$ we obtain a non-dimensional 
adimensional, luego del mismo modo ya explicado se determinan los parámetros $m_{s}$, $\tau_{\text {os }}$ y $\tau_{\text {LS }}$.

\section{DISPERSIÓN DE LOS PARÁMETROS}

La dispersión de los parámetros de las funciones de probabilidad acumulativa de fractura puede estimarse mediante la matriz de información de Fisher [13]. Los coeficientes de la matriz de Fisher se determinan usando la siguiente relación: graph, and in the same way as explained above we obtained $m_{s}, \tau_{0 s}$ and $\tau_{L S}$.

\section{DISPERSIONS OF THE PARAMETERS}

The dispersion of the parameters of the cumulative-provability-of-fracture functions may be estimated through Fisher's information matrix [13]. The coefficients of the Fisher matrix are determined using the following relationship:

$$
r_{i j}=-n \int\left[\frac{\partial^{2} \ln f(\tau ; \theta)}{\partial \theta_{i} \partial \theta_{j}}\right] f(\tau) d \tau
$$

donde $r_{i j}$ es el coeficiente $i, j, n$ es el tamaño de la muestra, $\theta$ son los parámetros y $f(\tau)=d F(\tau) / d \tau$ es la función de densidad de probabilidad de fractura. Si la función riesgo específico de fractura es una de Weibull con $\tau_{L}=0$, entonces los elementos de la matriz de Fisher son los siguientes where $r_{i j}$ is the coefficient $i, j, n$ is sample size, $\theta$ are the parameters, and $f(\tau)=d F(\tau) / d \tau$ is the density function of fracture probability. If the specific-risk-of-fracture function is a Weibull function with $\tau_{L}=0$ then the Fisher matrix elements are as follows:

$$
\begin{aligned}
r_{11}= & n\left(\frac{1}{g} \frac{\partial g}{\partial m}\right)^{2}+\frac{2 n}{g m} \frac{\partial g}{\partial m}(0.42277-\operatorname{lng}) \\
& +\frac{n}{m^{2}}\left(1.82379-0.84555 \operatorname{lng}+\ln ^{2} g\right) \\
r_{12}= & \frac{n}{\sigma_{0}}\left(\operatorname{lng}-\frac{m}{g} \frac{\partial g}{\partial m}-0.42277\right) \\
r_{22}= & n\left(\frac{m}{\sigma_{0}}\right)^{2}
\end{aligned}
$$

donde $\mathrm{g}=\mathrm{g}(\mathrm{m})$ para ambos casos de fragilidad, está dada por:

$$
\begin{aligned}
& g_{v}(m)=\frac{2 \pi L r^{2}}{V_{0}(m+2)} \\
& g_{S}(m)=\frac{2 \pi L r}{S_{0}}
\end{aligned}
$$

Luego, si consideramos sólo los casos donde $\tau_{\mathrm{L}}=0$, ecuaciones (6) y (10), para fragilidad volumétrica y superficial respectivamente, la matriz de varianzas y covarianzas se obtiene where $g=g(m)$ for both cases of brittleness is given by:

$$
\begin{aligned}
& ; \frac{\partial g_{v}}{\partial m}=-\frac{2 \pi L r^{2}}{V_{0}(m+2)^{2}} \\
& \therefore \frac{\partial g_{s}}{\partial m}=0
\end{aligned}
$$

Hence if we consider only the cases where $\tau_{L}=0$ as well as the respective equations (6) and (10) for volume brittleness and surface brittleness, then the matrix of variances and 
fácilmente mediante la inversión de la matriz de Fisher, con la condición que $r_{11}>0$. Por lo tanto, las varianzas y covarianzas se determinan como sigue: covariances is easily obtained through the inversion of the Fisher matrix, with the condition $r_{11} \geqq 0$. Therefore the variances and covariances are determined as follows:

$$
\begin{aligned}
\operatorname{Var}(m) & =\frac{r_{22}}{r_{11} r_{22}-r_{12}{ }^{2}} \\
\operatorname{Var}\left(\sigma_{0}\right) & =\frac{r_{11}}{r_{11} r_{22}-r_{12}^{2}} \\
\operatorname{Co-} \operatorname{var}\left(m, \sigma_{0}\right) & =\frac{r_{12}}{r_{12}^{2}-r_{11} r_{22}}
\end{aligned}
$$

\section{AGRADECIMIENTOS}

El autor desea expresar su reconocimiento al Profesor P. Kittl por sus sugerencias y comentarios, al Fondo Nacional de Desarrollo Científico y Tecnológico (FONDECYT) por los fondos asignados a través de los proyectos $545 / 85$ y $516 / 88$.

\section{ACKNOWLEDGEMENTS}

The author would like to express their gratitude to Professor P. Kittl for his suggestions and discussions, to the Fondo Nacional de Desarrollo Científico y Tecnológico (FONDECYT) for the funds granted through Project $N^{\circ}$ 545/85 and Project $N .^{\circ} 516 / 88$, and to $R$. Toledo for his assistance in the rendering of the manuscript.

\section{REFERENCIAS (REFERENCES)}

[1] WEIBULL, W.: Ingeniors Vetenskaps Akad. Hand1. 151 (1939) 1-45.

[2] FREUDENTHAL, A. M., In: Fracture, and Advanced Treatise, Academic Press, New York (1968) 591-619.

[3] KITTL, P.: J. App1. Mech., 51 (1984) 221-222.

[4] RADFORD, K. C. and LANGE, F. F.: J. Am. Ceram. Soc., 61 (1978) 211-213.

[5] LAMON, J. and EVANS, A. G.: J. Am. Ceram. Soc., 66 (1983) 177-182.

[6] PETROVIC, J. J. and STOUT, M. G.: J. Am. Ceram. Soc., 64 (1981) 656-660.

[7] PETROVIC, J. J. and STOUT, M. G.: J. Am. Ceram. Soc., 64 (1981) 661-666.

[8] StOUT, M. G. and PETROVIC, J. J., J. Am. Ceram. Soc.,67 (1984) 14-18.

[9] PETROVIC, J. J. and STOUT, M. G.: J. Am. Ceram. soc., 67 (1984) 18-23.

[10] KITTL, P.: Res Mech., 1 (1980) 161-165.

[11] TRUSTRUM, K. and JAYATILAKA, A. de S.: J. Mater. Sci., 14 (1979) 1.080-1.084.

[12] LEON, M. and KITTL, P.: J. Mater. Sci., 20 (1985) 3.778-3.782.

[13] KITTL, P., LEON, M. and CAMILO, G. M., In: Advances in Fracture Research Vol. 4, Pergamon Press, Oxford, 1984, p. $2.743-2.750$ 